\title{
Covid-19: NHS will restart some paused services this week
}

\section{Gareth lacobucci}

The BMJ

Some NHS services that were temporarily stopped to release capacity for dealing with the covid-19 pandemic will restart from today, the health secretary has announced.

Matt Hancock said that the "restoration" of other NHS services would initially focus on the most urgent services, such as for cancer and mental health. He said that the recommencement was possible because the number of hospital admissions from covid-19 was beginning to fall in most parts of the country, suggesting that the UK might be past its first peak of the virus.

Hancock told the daily Downing Street briefing on 27 April that decisions on resuming services would be made locally and on a hospital-by-hospital basis. "The exact pace of the restoration will be determined by local circumstances on the ground, according to local need and according to the amount of coronavirus cases that that hospital is having to deal with," he said.

On 17 March, ${ }^{1}$ NHS hospitals in England were told to suspend all non-urgent elective surgery to help free up 30000 of the English NHS's 100000 general and acute beds to deal with the covid-19 pandemic.
Responding to Hancock's announcement, Niall Dickson, chief executive of the NHS Confederation, which represents healthcare organisations, said that now was the right time to resume operations and other treatments in a managed way.

He said, "The NHS has remained open for business for critical and other urgent care, and it has not been overwhelmed. But freeing up 33000 hospital beds at pace and suspending non-urgent procedures has created a massive backlog, and it will mean increased pressure on hospitals, community, GP services, and social care.

"Starting this work again needs to be done carefully, with local health leaders deciding what is best for their local communities and what can be managed. We know some staff will need downtime to recover after what they have been through."

lacobucci G. Covid-19: all non-urgent elective surgery is suspended for at least three months in England. BMJ 2020;368:m1106. 10.1136/bmj.m1106 32188602

Published by the BMJ Publishing Group Limited. For permission to use (where not already granted under a licence) please go to http://group.bmj.com/group/rights-licensing/ permissions 